\title{
The Impact of Corporate Governance on Working Capital Management Efficiency: Evidence from the Listed Companies in the Consumer Services Sector in Botswana
}

\author{
Sathyamoorthi C. R. ${ }^{1}$, Christian J. Mbekomize ${ }^{1}$, Mogotsinyana Mapharing ${ }^{1} \&$ Popo Selinkie ${ }^{1}$ \\ ${ }^{1}$ Faculty of Business, University of Botswana, Gaborone, Botswana \\ Correspondence: Sathyamoorthi C. R., Faculty of Business, University of Botswana, Private Bag 00701, \\ Gaborone, PO Box 70430, Botswana. Tel: 267-7173-6816. E-mail: sathyamo@mopipi.ub.bw; \\ sathyamcr@gmail.com
}

Received: October 6, 2018

Accepted: November 16, $2018 \quad$ Online Published: November 22, 2018

doi:10.5539/ijef.v10n12p135

URL: https://doi.org/10.5539/ijef.v10n12p135

\begin{abstract}
The paper presents the findings of the analysis of the impact of corporate governance mechanisms on working capital management efficiency in the listed companies of the Consumer service sector in Botswana. Eight corporate governance elements and seven working capital components were extracted from the annual reports of a sample of six companies for the period 2012 to 2017 for the analysis. Thirty six observations were obtained. Pearson correlations were executed to determine the relationship between corporate governance elements and working capital components. OLS regression analysis was performed to establish the explaining power of the combination of corporate governance elements on each of the working capital components. The correlation analysis shows that number of non-executive directors has a significant negative but moderate relationship with cash conversion cycle and number of board subcommittees has significant positive but moderate relationship with Debt ratio. The regression results suggest that corporate governance mechanisms have a significant impact on working capital management, the highest impact being reflected on inventory conversion period. The implications of these findings are that boards of directors have a significant role to play in working capital management efficiency of the companies they govern. They should therefore continue providing attainable policies on working capital management and remain vigilant on demanding feedback on their implementations.
\end{abstract}

Keywords: corporate governance, working capital, consumer service sector, inventory conversion period, Botswana

\section{Introduction}

\subsection{Background Information}

Efficient working capital management is essential for most firms (Gill \& Biger, 2013). The importance of efficiently managed working capital has been found to be indisputable in previous studies (Meshack, 2015). In particular, the prior studies have associated the importance of working capital management efficiency (WCME) with firm's profitability, value, and solvency (Kamel, 2016). Therefore, working capital management (WCM) plays a key role in the successful running of every business enterprise as it has a direct impact on its liquidity and profitability. Deloof (2003) found a significant negative relationship between gross operating income and the number of days of accounts receivable, inventories and accounts payable of Belgian firms. These results suggest that corporate managers can create value for their shareholders by reducing the number of days accounts receivable are collected and by cutting inventories' shelf- life to a reasonable minimum (Deloof, 2003).

Components of working capital include current assets and current liabilities, which include accounts receivable, inventory, cash and payables. Firms tend to face a trade-off when deciding on the level of working capital to maintain. In this respect, working capital management is needed to minimize the risk of running short on liquidity, although it is costly to hold too much working capital as it decreases the return on invested capital (Brigham \& Daves, 2007). By extension, this emanates from the inherent trade-off between liquidity and profitability against the risk of facing bankruptcy (Kargar \& Blumenthal, 1994). Furthermore, the level of working capital that a firm maintains affects its solvency, liquidity, and profitability (Mukhopadhyay, 2004).

Corporate governance is considered to be a very important condition for sustainable economic growth of any 
country. For the private sector, significant benefits are linked to higher corporate governance standards. These benefits include better access to external finance, lower costs of capital and better firm performance. Good governance is acknowledged as essential for achieving the United Nations Millennium Development Goals and as a pre-condition for sustainable economic growth (Elhabib, Rasid, \& Basiruddin, 2015). In highlighting the importance of corporate governance Claessens (2003) pointed out that corporate governance covers the relationship between shareholders, creditors and corporations; between institutions and corporations; and between employees and corporations. Corporate governance could also include the corporate social responsibility that is, the environment and culture. A good governance structure ensures corporate accountability and enhances the confidence of investors, reliability of financial information that are made available to the public as well as the efficiency of the capital market (Alnaser, Shaban, \& Al-Zubi, 2014).

Karani (2013) highlighted that corporate governance play a significant role in controlling working capital management. This is achieved by formulating sound policies that govern efficient working capital management. According to Gill and Shah (2012), CEO and board of directors are entrusted with the task of formulating policies that relate to cash management and for that reason they play an important part in improving the efficiency in working capital management. Gill, Biger, and Obradovich (2014) found that poor working capital management policies, induced by weak corporate governance have a negative effect on shareholders' wealth in the business. The CEO and the board of directors are responsible for formulating working capital and other policies in the organization. Efficient corporate governance will result in effective working capital management, which in turn result in improved liquidity and profitability; ensuring maximum return to shareholders on their invested capital (Kamel, 2016). However, managers prefer high levels of investment in working capital to minimize the risk of bankruptcy and for the precautionary motive of holding cash, thus reducing the pressure exerted on managers to perform well (Wasiuzzaman \& Arumugam, 2013). According to Drobetz, Grüninger, and Hirschvogl (2010), management tend to hold on to resources and waste them on inefficient investments instead of distributing them to shareholders, and as a result, creating an agency problem. In this regard, corporate governance has a fundamental role in the efficiency of working capital management through monitoring the working capital policies that are formulated by the board of directors and the CEO. Hence, inefficient monitoring of WCM is expected to adversely affect firm value.

\subsection{Problem Statement}

The study examines the impact of corporate governance practices on working capital management efficiency among the listed companies in the consumer services sector in Botswana. Previous research in other countries on corporate governance and its effect on working capital efficiency has reported mixed results (Kamel, 2016). Accordingly, further investigation of the impact of corporate governance on working capital management is well deserved, especially in the context of a developing nation where monitoring of policies may be problematic. Moreover, research on this area is scanty and untouched in Botswana's perspective. The study, therefore, fills the research gap by contributing to the financial literature on how corporate governance practices and models can influence working capital management efficiency in firms.

\subsection{Objectives}

The aim of the study is to explore the effect of Corporate Governance on Working Capital Management Efficiency (WCME) in the listed companies in the Consumer Services Sector in Botswana. More specifically, the study assesses the impact of key corporate governance variables (Board size, Executive and non-executive directors, Male directors, Female directors, Board gender diversity, Number of sub-committee and Board meeting frequency) on key working capital management components (Average Collection Period (ACP); Inventory Conversion Period (ICP); Average payment Period (APP); Cash Conversion Cycle (CCC); Debt Ratio (DR); Current Ratio (CR) and Quick Ratio (QR)).

\subsection{Significance of the Study}

The study has both managerial and academic implications. It is expected to inform management regarding the fundamental relationship between corporate governance mechanisms and working capital components. Further, the study will point management and policy makers to critical components of corporate governance and working capital which they should concentrate on when formulating policies that can spearhead suitable working capital management policies. The study also contributes to the existing literature on the topic. The findings will assist future researchers to appreciate the relationship between corporate governance practices and working capital management efficiency in Botswana context. Finally, the study will also benefit the stakeholders and prospective investors by delineating critical governance components to companies' performance. 


\section{Theoretical and Empirical Perspective}

\subsection{Theoretical Review}

The theoretical framework is the structure that can support or hold a theory of a research study and exhibits an understanding of the concepts and theories that are pertinent to the topic of the research. This study focused on two important theories, namely; Agency Theory and Stewardship Theory.

\subsubsection{Agency Theory}

Agency theory is fundamental to corporate governance. It explains the relationships between one party (principal) who delegates the work to another party (agent). When the agent acts for the principal, it has the resemblance of a behavior of performing for the benefit of the principal or acting as principal's representative (Fayezi et al., 2012). It focuses on a set of schemes that help govern a corporate, which is characterized by large group of owners who permit a separate group of individuals to control and manage their investments in the business for their future profits. It is considered as one of the oldest theory in the literature of management and economics (Panda \& Leepsa, 2017). Berle and Means (1932) introduced the discussion on separation of ownership and control in US firms and Jensen and Meckling (1976) integrated the elements from the theory of agency, the theory of property rights and the theory of finance to develop a theory of ownership structure for a business enterprise. The theory has been found useful for investigating relationships between principals and agents in many disciplines. Ronen, Kashi, and Balachandran (1995), highlighted the uses of Agency Theory in managerial accounting. Bergen, Dutta, and Walker (1992) attempted to clarify market implications of agency theory by describing its major concepts. Fama and Jensen (1983) developed a theory that focused on steps on organizational decision making process and setting up devices for controlling agency problems in the decision making process.

The application of agency theory on corporate governance is gaining momentum. The theory is important because it forms the basis for framing policies regarding the proper governance of organizations. Corporate governance mechanisms such as enterprise information disclosure, board independence, external audit, laws and regulations etc. are introduced essentially to control the agency problem and to confirm that managers always act in the best interest of the owners of the business (Homayoun \& Homayoun, 2015).

\subsubsection{Stewardship Theory}

Stewardship theory argues that managers of a firm are stewards of the owners, where both have common goals. Stewardship theory provides a normative view into the nature of managers. Based on social-psychology doctrines and leadership theories, stewardship theory provides a possible alignment between principals and agents where agents act in a community-based manner (Davis, Frankforter, Vollrath, \& Hill, 2007). According to Sundaramurthy and Lewis (2003), stewardship theory incorporates a collaborative approach, taking insights from sociology, psychology, and supports board-management relationships in decision making by empowering managers of the firm. Yusoff and Alhaji (2012) highlighted that the stewardship theory believes in a strong relationship between managers and business success, thereby maximizing the wealth of shareholders. Thus the managers, according to stewardship theory, satisfy all interested parties, thereby ensuring a more balanced corporate governance for the organization.

\subsection{Empirical Literature Review}

Academicians and researchers have assessed the impact of corporate governance on the working capital management of listed firms in various sectors. A review of those studies is presented below:

Ahmad, Ahmed, and Samim (2018) used multiple regression analysis to examine the impact of corporate governance on working capital management on 40 listed Pakistani firms for the period 2008-2012. The findings highlighted that governance variables had significant influence on working capital efficiency. Cash conversion cycle and current ratio were used as parameters for working capital management while CEO tenure, CEO duality, audit committee and board size were identified as variables for corporate governance.

Ali and Shah (2017) collected a sample of 62 listed manufacturing firms of Pakistan stock exchange to investigate the impact of corporate governance on working capital management in manufacturing firms in Pakistan for the period 2014-16. Data on audit committee, number of board meetings, board size, CEO duality and gender effect were used to represent corporate governance practices while cash conversion cycle and cash holdings were identified as determinants of working capital efficiency. The authors' results showed that audit committee, board size and gender effect lead to improved use of working capital.

Njoku (2017) carried out a study on a sample of 89 listed Nigerian organizations for the period 2013-2014. CEO 
duality, CEO tenure, board size and audit committee were taken as corporate governance parameters and working capital management was measured using current assets, current liabilities, current ratio and cash conversion cycle. Regression analysis of the variables indicated that the size of board of directors and that of audit committee were significantly related to Working capital management, whereas CEO tenure and CEO duality had no relationship with Working capital management.

A study was conducted by Sadegh zadeh (2016) on the impact of corporate governance on cash management efficiency in 15 listed companies in the industry of machinery and equipment in Tehran for the period 2006-2014. The study used CEO tenure duration and ratio of non-board members as variables of corporate governance practices and cash conversion cycle to measure working capital efficiency. The findings indicated a significant positive relationship between corporate governance and working capital management component of cash conversion cycle.

Al-Rahahleh (2016) collected data for the period 2009-2013 to study the impact of corporate governance on cash conversion cycle among all listed companies on Amman Stock Exchange. The study used OLS regression to analyze the data on cash conversion cycle, board size, number of board meetings and audit committee. The findings indicated that cash conversion cycle is negatively affected by corporate governance quality, which lead to the conclusion that Jordan-based industries should improve their compliance with corporate governance practices to enhance working capital efficiency.

Goel, Bansal, and Sharma (2015) examined the impact of corporate governance practices on working capital management of 127 large Indian manufacturing sector firms for the period 2004-13 and found that corporate governance parameters of board size, number of independent directors and the percentage of independent members in the audit committee affect significantly the working capital management efficiency of the selected firms. The study also revealed that an increase in the independence of board and audit committee lead to adoption of a conservative approach to management of short-term capital, which negatively affected working capital efficiency. It was also noted that the increase in board size weakened control.

Chaudhry and Ahmad (2015) studied the impact of corporate governance on working capital management efficiency of listed manufacturing firms in Pakistan for the period 2010-2013 and found that corporate governance practices have a significant influence on working capital management efficiency. The study used Board size, Audit committee, Board committees, Board meetings, Board independence (number of outside directors/total number of directors) as independent variables and average collection period, average payment period, inventory turnover period, and cash conversion cycle as dependent variables. The control variables included sales growth, firm size, return on assets and leverage.

A study by Jamalinesari and Soheili (2015) used a sample of 115 listed companies in the Tehran's stock exchange for the period 2008 to 2013 to measure the impact of corporate governance on the efficiency of working capital management. The corporate governance mechanisms used included board size, independence of board of directors, institutional stockholders and ownership concentration. Working capital management parameters included average payment period, cash conversion cycle, cash holding level and current ratio. The results indicated that corporate governance mechanisms play an important role in improving the efficiency of working capital among the selected enterprises.

Mansour, Seid and Rahmatollah's study (as cited in Ali \& Shah, 2017) on corporate governance and its impact on working capital management in 75 listed companies in Tehran for the period 2009-2014, revealed that CEO duality and institutional ownership influence accounts receivable, accounts payable, inventory, cash conversion cycle and current ratio. CEO tenure however, was found to have no influence on cash conversion efficiency. The study used CEO duality and CEO tenure as independent variable and accounts receivable, accounts payable, cash conversion cycle, current ratio and cash conversion efficiency as dependent variables.

Meshack (2015) examined the impact of corporate governance on working capital management efficiency in selected manufacturing firms in Nairobi County. The author used Board size, board composition, CEO Tenure, board effectiveness in terms of leadership, stewardship monitoring and reporting, frequency of board meetings, board members experience and qualification, multiple directorship and directors' remuneration, internal audit and shareholders' interest as parameters to measure corporate governance practices and concluded that a significant percentage of the variations in working capital efficiency were related to Board structures, internal audit and the shareholders' interest. The study found that board structure has the highest impact on working capital efficiency than internal audit and shareholders' interest.

Kamel (2016) investigated the impact of corporate governance and firm maturity on working capital management efficiency among 583 listed European Firms for the period 2002-2013. The study used cross 
section random effect panel discussion regression model where board independence, board size, CEO duality, number of board meetings, audit committee independence and ownership concentration were identified as corporate governance parameters while accounts receivable days, accounts payable days, inventory days held, cash conversion cycle, cash holdings, current ratio and cash conversion efficiency were used as dependent variables. The findings revealed that both corporate governance and firm maturity are significant factors that influence working capital management efficiency.

Dolatabadi's study (as cited in Ali \& Shah, 2017), analyzed the data set of 70 listed companies in Tehran stock exchange and the findings showed that corporate governance play an important role in the management of working capital. The study used CEO tenure, CEO duality and board size as corporate governance variables whereas working capital parameters included accounts receivable, accounts payable, inventory and cash holdings. Sales growth, firm size and firm performance were used as control variables.

Faradonbeh and Dolatabadi (2015) used three parameters of corporate governance mechanisms to analyze the impact on current asset management of selected listed companies in Tehran for the period 2008-2012. Corporate governance parameters consisted of CEO tenure, CEO duality and board size and the dependent variables for current asset management were inventory, accounts receivable, cash holdings and accounts payable. Sales growth, firm size and firm performance were used as control variables. The outcome of multi-variable regression analysis showed that the variables were significantly related.

Kamau and Basweti (2013) examined the relationship between corporate governance and working capital management efficiency in Kenyan firms for the period 2006 to 2012. Corporate governance practices were measured using Board meeting, Board committee, CEO duality, Board size, CEO tenure and Directors' remuneration. Annual sales, current assets, current liabilities and size of working capital were identified as parameters to indicate the working capital efficiency. Using independent one-way ANOVA test and independent t-tests to determine the level of significance, the results indicated that there was no statistically significant relationship between corporate governance and working capital management efficiency in the selected firms.

Gill and Biger (2013) focused on the impact of corporate governance on working capital management efficiency in 180 listed American manufacturing firms for the period 2009 to 2011. To assess the impact, the study used CEO tenure, CEO duality, board size and audit committee as independent variables, while accounts receivable, inventory, accounts payable and cash conversion cycle were chosen as dependent variables. Regression analysis of the variables showed that CEO duality and internationalization of the organization improve the efficiency to manage accounts receivable and accounts payable; internationalization of the firm improves inventory and cash conversion cycle management efficiency; CEO tenure, firm size and financial performance improve efficiency in cash and current ratio management and CEO duality and financial performance has a direct impact in improving cash conversion efficiency. The study also found that that board size did not improve the efficiency of current ratio management.

Karani (2013) studied the listed Kenyan manufacturing firms to measure the impact of corporate governance on working capital management. Adopting a regression model, the study analyzed the identified corporate governance determinants of CEO tenure, board size and audit committee and the working capital management parameters, namely, accounts receivable, accounts payable and inventory of 15 firms for the period 2008 to 2012 . The findings in general highlighted that corporate governance practices play an important part in the improvement of working capital efficiency.

Gill and Shah (2012) used a sample of 166 Canadian listed firms for the period 2008-2010 to investigate the determinants of corporate cash holdings in Canada and found that market-to-book ratio, net working capital, leverage, firm size, board size and the CEO duality affect significantly the corporate cash holdings in Canada.

Lau and Block (2012) looked at the controlling founders and families and their influence on the level of cash holdings of the business enterprise and concluded that founder firms retain a significantly higher level of cash holdings than family firms and that the presence of founders as managers help reduce the agency costs of cash holdings.

Afa and Adnan's study (as cited in Gill \& Shah, 2012) examined the level of corporate cash holdings of non-Pakistani firms for the period 1998-2005 and found that firm size, cash flow, cash flow uncertainty, net working capital and leverage significantly affect the cash holdings of non-financial firms in Pakistan.

Kuan, $\mathrm{Li}$, and $\mathrm{Chu}$ (2011) examined the association between corporate governance and cash policy among 1164 organizations in Taiwan for the period 1997 to 2008, within family-controlled firms and the results indicated that separation of seat control rights and cash flow rights and the chair duality, affected significantly the cash policy 
within different levels of cash holdings in business enterprises.

An investigation by Dittmar and Mahrt-Smith (2007) on the influence of corporate governance on cash holdings using the data set of 1958 publically traded US firms for the period 1990 to 2003, revealed that corporate governance of an organization has significant impact on the firm value through its effect on cash policy. The study also brought to light that poor governance of firms could drain excess cash faster than good governance.

\subsection{Conceptual Framework}

Drawing from literature and based on the objectives of the study, the following conceptual model has been developed. The framework shows the connectivity between corporate governance mechanisms and working capital components.

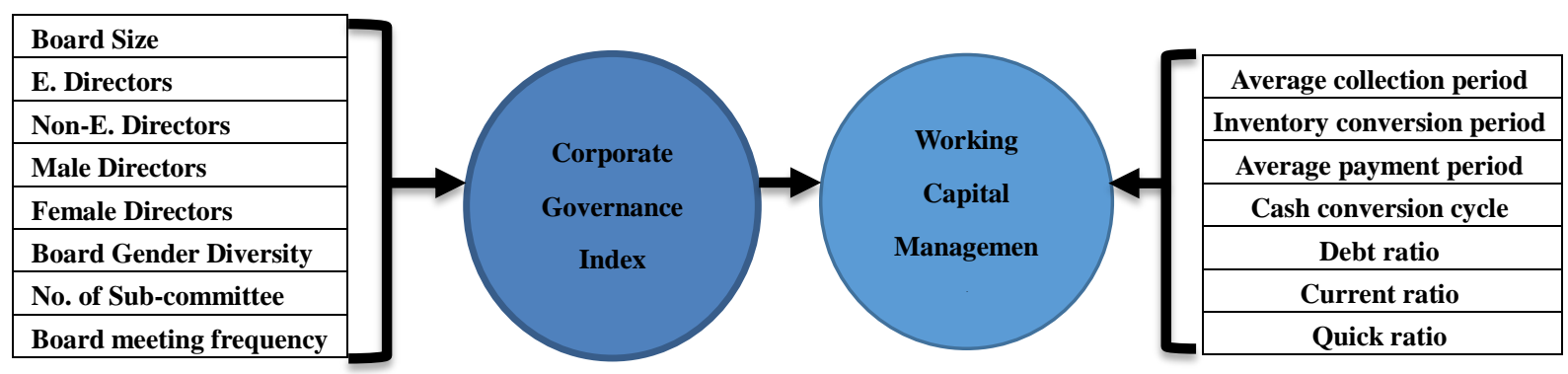

Source: Authors.

\section{Methodology}

The current study employed non-experimental causality research design to investigate the effect of corporate governance on working capital management efficiency of listed companies in the consumer services sector in Botswana for the period 2012 to 2017. The targeted population comprised eight companies in the sector of interest but only six companies were included in the study since one company presented the financial statements in a format which made the extraction of required information difficult and the other company was still new hence did not have data for the whole period under study. Data was extracted from annual reports found on the websites of the targeted companies. In this regard, 36 observations (6 companies x 6 years) were generated.

Drawing from literature, the study examined the relationship between seven working capital variables as dependent variables and eight corporate governance variables as independent variables. Working capital variables included Average Collection Period, Inventory Conversion Period, Average Payment Period, Cash Conversion Cycle, Debt Ratio, Current Ratio and Quick Ratio. The corporate governance variables used were Board size, Executive board members, Non-executive, Male directors, Female directors, Board Gender Diversity, Number of sub-committees and Board meeting frequency.

Table 2 reflects the measurements of variables used in this study which are consistent with those appearing in prior studies (Gill \& Biger, 2013; Chaudhry \& Ahmad, 2015; Deloof, 2003; Lazaridis \& Tryfonidis, 2006).

Table 1. Measurement of working capital and corporate governance variables

\begin{tabular}{lcl}
\hline Variables & Abbreviation & Measurements \\
\hline Dependent Variables and Measurement & & \\
Average Collection Period & ACP & Accounts Receivable / Sales *365 \\
Inventory Conversion Period & ICP & Average Inventory/Cost of Goods Sold*365 \\
Average Payment Period & APP & Accounts Payable/ Cost of Goods Sold *365 \\
Cash Conversion Cycle & CCC & ACP+ICP-APP \\
Debt Ratio & DR & Total Liabilities/Total Assets \\
Current Ratio & CR & Current Assets/Current Liabilities \\
Quick Ratio & QR & Current Assets less Closing Inventory/ Current Liabilities \\
Independent Variables and Measurement & & \\
Board size & BSE & Total number of persons serving in the board of directors \\
Executive & EXC & Total number of persons serving as executive directors in the board \\
Non-executive & NEX & Total number of persons serving as non-executive directors in the board \\
Male directors & MDS & Total number of male directors in the board of directors \\
\hline
\end{tabular}




\begin{tabular}{|c|c|c|}
\hline Female directors & FDS & Total number of female directors in the board of directors \\
\hline Board Gender Diversity & BGD & $\begin{array}{l}\text { Percentage of female directors divided by the total number of directors in } \\
\text { the board }\end{array}$ \\
\hline No of sub-committee & NSC & Total number of active subcommittee \\
\hline Board meeting frequency & $\mathrm{BMF}$ & Number of board meetings held in a given period \\
\hline
\end{tabular}

The data was analyzed using descriptive statistics, Pearson correlation and regression analysis. The study used Ordinary Least Square regression model to explain the relationship between corporate governance and working capital management. The model was constructed as follows:

$$
Y=\alpha+\beta_{1} X_{1}+\beta_{2} X_{2}+\beta_{3} X_{3}+\beta_{4} X_{4}+\beta_{5} X_{5}+\beta_{6} X_{6}+\beta_{7} X_{7}+\beta_{8} X_{8}+\varepsilon
$$

Where;

Y presents working capital variable measure which includes Average Collection Period, Inventory Conversion Period, Average Payment Period, Cash Conversion Cycle, Debt Ratio, Current Ratio and Quick Ratio.

$\alpha$ represents the value that $Y$ will have when all independent variables are equal to zero.

$\beta_{1}, \beta_{2}, \beta_{3}, \beta_{4}, \beta_{5}, \beta_{6}, \beta_{7}$, and $\beta_{8}$ represent the quantified effect that each corporate governance variable has on the working capital variable.

$\mathrm{X}_{1}$ = Total number of persons serving in the board of directors;

$\mathrm{X}_{2}$ = Total number of persons serving as executive directors in the board;

$\mathrm{X}_{3}=$ Total number of persons serving as non-executive directors in the board;

$\mathrm{X}_{4}=$ Total number of male directors in the board;

$\mathrm{X}_{5}=$ Total number of female directors in the board;

$\mathrm{X}_{6=}$ Percentage of female directors divided by the total number of directors in the board;

$\mathrm{X}_{7}=$ Total number of active subcommittees;

$\mathrm{X}_{8}=$ Number of board meetings held in a given period;

$\varepsilon$ is an error term.

The following seven models were tested:

$$
\begin{aligned}
& A C P=\alpha+\beta_{1} B S E+\beta_{2} E X C+\beta_{3} N E X+\beta_{4} M D S+\beta_{5} F D S+\beta_{6} B G D+\beta_{7} N S C+\beta_{8} B M F+\varepsilon \\
& I C P=\alpha+\beta_{1} B S E+\beta_{2} E X C+\beta_{3} N E X+\beta_{4} M D S+\beta_{5} F D S+\beta_{6} B G D+\beta_{7} N S C+\beta_{8} B M F+\varepsilon \\
& A P P=\alpha+\beta_{1} B S E+\beta_{2} E X C+\beta_{3} N E X+\beta_{4} M D S+\beta_{5} F D S+\beta_{6} B G D+\beta_{7} N S C+\beta_{8} B M F+\varepsilon \\
& C C C=\alpha+\beta_{1} B S E+\beta_{2} E X C+\beta_{3} N E X+\beta_{4} M D S+\beta_{5} F D S+\beta_{6} B G D+\beta_{7} N S C+\beta_{8} B M F+\varepsilon \\
& D R=\alpha+\beta_{1} B S E+\beta_{2} E X C+\beta_{3} N E X+\beta_{4} M D S+\beta_{5} F D S+\beta_{6} B G D+\beta_{7} N S C+\beta_{8} B M F+\varepsilon \\
& C R=\alpha+\beta_{1} B S E+\beta_{2} E X C+\beta_{3} N E X+\beta_{4} M D S+\beta_{5} F D S+\beta_{6} B G D+\beta_{7} N S C+\beta_{8} B M F+\varepsilon \\
& Q R=\alpha+\beta_{1} B S E+\beta_{2} E X C+\beta_{3} N E X+\beta_{4} M D S+\beta_{5} F D S+\beta_{6} B G D+\beta_{7} N S C+\beta_{8} B M F+\varepsilon
\end{aligned}
$$

\section{Results Analysis and Discussion,}

Descriptive statistics as shown in Table 2.

Table 2. Descriptive statistics

\begin{tabular}{lccccc}
\hline & N & Minimum & Maximum & Mean & Std. Deviation \\
\hline ACP & 36 & .32783 & 29.49625 & 10.1184443 & 8.18694440 \\
ICP & 36 & 4.75245 & 155.82078 & 53.5391585 & 45.66198120 \\
APP & 36 & 13.17437 & 144.68510 & 50.4712691 & 33.34400751 \\
CCC & 36 & -105.73308 & 121.68976 & 13.1536913 & 52.52783526 \\
DR & 36 & .20217 & .57524 & .3917879 & .10680076 \\
CR & 36 & .92953 & 6.93916 & 2.1764613 & 1.41925242 \\
QR & 36 & .38822 & 5.41697 & 1.6904865 & 1.14989259 \\
BSE & 36 & 5 & 16 & 9.31 & 2.303 \\
EXC & 36 & 1 & 5 & 2.83 & 1.183 \\
\hline
\end{tabular}




\begin{tabular}{lccccc}
\hline NEX & 36 & 3 & 11 & 6.47 & 2.274 \\
MDS & 36 & 4 & 16 & 8.67 & 2.597 \\
FDS & 36 & 0 & 2 & .61 & .599 \\
BGD & 36 & .00000 & 1.14290 & .1013558 & .19212232 \\
NSC & 36 & 1 & 6 & 2.67 & 1.707 \\
BMF & 36 & 1 & 7 & 3.89 & .950 \\
\hline
\end{tabular}

Table 2 shows that on average the sampled companies give their credit customers only 10 days to pay while they take about 53 days to pay their suppliers. It also shows that it takes the companies 50 days to sell their inventory and their cash conversion period is almost 13 days on average. This signifies a good liquidity position of the sampled companies which is supported by current ratios. The current assets on average cover the current liabilities 2 times while the current assets less inventory cover the current liabilities 1.7 times. It is also evident from Table 2 that the companies in the sample of this study are moderately leveraged since their total liabilities are about $39 \%$ of total assets as measured by the debt ratio.

The average size of the board of directors in the sampled companies is almost 9 members, the minimum being 5 members and the maximum being 16 members. The mean of executive directors in the board of directors is around 3 while the non-executive directors' average is about 6 . Table 2 also shows that the board of directors of sampled companies are heavily dominated by male directors. While the mean of male directors is around 9 members, the female directors mean is 0.60 giving us a ratio of gender balance of almost $10 \%$. The average number of sub-committees of the board of directors range from 1 to 6 with a mean of almost 3 committees per company. On average the board of directors in the sample companies meet 4 times a year.

Table 3. Pearson correlation between variables and their significant levels

\begin{tabular}{|c|c|c|c|c|c|c|c|c|c|c|c|c|c|c|c|}
\hline & & $\mathrm{ACP}$ & ICP & APP & $\mathrm{CCC}$ & DR & $\mathrm{CR}$ & QR & BSE & EXC & NEX & MDS & FDS & BGD & $\mathrm{NSC}$ \\
\hline \multirow[t]{2}{*}{$\mathrm{ICP}$} & Pearson Correlation & $-.575^{* *}$ & 1 & & & & & & & & & & & & \\
\hline & Sig. (2-tailed) & .000 & & & & & & & & & & & & & \\
\hline \multirow[t]{2}{*}{ APP } & P Pearson Correlation & .039 & .018 & 1 & & & & & & & & & & & \\
\hline & Sig. (2-tailed) & .820 & .919 & & & & & & & & & & & & \\
\hline \multicolumn{2}{|c|}{ CCC Pearson Correlation } & $-.369^{*}$ & $.769^{* *}$ & $-.613^{* *}$ & 1 & & & & & & & & & & \\
\hline & Sig. (2-tailed) & .027 & .000 & .000 & & & & & & & & & & & \\
\hline \multirow[t]{2}{*}{ DR } & Pearson Correlation & .225 & -.208 & .070 & -.190 & 1 & & & & & & & & & \\
\hline & Sig. (2-tailed) & .187 & .223 & .684 & .267 & & & & & & & & & & \\
\hline \multirow[t]{2}{*}{$\mathrm{CR}$} & Pearson Correlation & $-.405^{*}$ & $.808^{* *}$ & -.156 & $.739^{* *}$ & $-.393^{*}$ & 1 & & & & & & & & \\
\hline & Sig. (2-tailed) & .014 & .000 & .364 & .000 & .018 & & & & & & & & & \\
\hline \multirow[t]{2}{*}{ QR } & Pearson Correlation & $-.350^{*}$ & $.724^{* *}$ & -.055 & $.610^{* *}$ & $-.490^{* *}$ & $.958^{* *}$ & 1 & & & & & & & \\
\hline & Sig. (2-tailed) & .036 & .000 & .749 & .000 & .002 & .000 & & & & & & & & \\
\hline \multirow[t]{2}{*}{ BSE } & E Pearson Correlation & .210 & -.285 & $.631^{* *}$ & $-.616^{* *}$ & .162 & -.265 & -.088 & 1 & & & & & & \\
\hline & Sig. (2-tailed) & .219 & .091 & .000 & .000 & .345 & .119 & .609 & & & & & & & \\
\hline \multicolumn{2}{|c|}{ EXC Pearson Correlation } & $-.470^{* *}$ & $.670^{* *}$ & $.444^{* *}$ & .229 & -.015 & $.480^{* *}$ & $.438^{* *}$ & .281 & 1 & & & & & \\
\hline & Sig. (2-tailed) & .004 & .000 & .007 & .180 & .931 & .003 & .008 & .096 & & & & & & \\
\hline \multicolumn{2}{|c|}{ NEXPearson Correlation } & $.457^{* *}$ & $-.638^{* *}$ & $.408^{*}$ & $-.743^{* *}$ & .172 & $-.518^{* *}$ & -.317 & $.866^{* *}$ & -.235 & 1 & & & & \\
\hline & Sig. (2-tailed) & .005 & .000 & .013 & .000 & .316 & .001 & .060 & .000 & .167 & & & & & \\
\hline \multicolumn{2}{|c|}{ MDSPearson Correlation } & .117 & -.124 & $.672^{* *}$ & $-.516^{* *}$ & .190 & -.155 & .000 & $.968^{* *}$ & $.418^{*}$ & $.763^{* *}$ & 1 & & & \\
\hline & Sig. (2-tailed) & .498 & .472 & .000 & .001 & .266 & .367 & .998 & .000 & .011 & .000 & & & & \\
\hline \multirow[t]{2}{*}{ FDS } & S Pearson Correlation & .250 & $-.511^{* *}$ & $-.440^{* *}$ & -.127 & -.191 & $-.334^{*}$ & $-.345^{*}$ & $-.346^{*}$ & $-.659^{* *}$ & -.008 & $-.563^{* *}$ & 1 & & \\
\hline & Sig. (2-tailed) & .141 & .001 & .007 & .462 & .265 & .046 & .040 & .039 & .000 & .962 & .000 & & & \\
\hline \multicolumn{2}{|c|}{ BGDPearson Correlation } & -.061 & -.244 & -.241 & -.068 & .113 & -.258 & -.323 & -.322 & $-.356^{*}$ & -.141 & $-.398^{*}$ & $.457^{* *}$ & 1 & \\
\hline & Sig. (2-tailed) & .726 & .152 & .156 & .693 & .512 & .128 & .055 & .055 & .033 & .410 & .016 & .005 & & \\
\hline \multicolumn{2}{|c|}{ NSC Pearson Correlation } & $.412^{*}$ & $-.509^{* *}$ & .136 & $-.465^{* *}$ & $.718^{* *}$ & $-.574^{* *}$ & $-.603^{* *}$ & $.419^{*}$ & -.141 & $.498^{* *}$ & $.412^{*}$ & -.158 & -.109 & 1 \\
\hline & Sig. (2-tailed) & .013 & .002 & .428 & .004 & .000 & .000 & .000 & .011 & .411 & .002 & .012 & .356 & .526 & \\
\hline \multicolumn{2}{|c|}{ BMFPearson Correlation } & .302 & $-.470^{* *}$ & -.136 & -.276 & .281 & $-.410^{*}$ & $-.371^{*}$ & .251 & -.297 & $.409^{*}$ & .193 & .123 & -.096 & $.593^{* *}$ \\
\hline & Sig. (2-tailed) & .074 & .004 & .430 & .103 & .097 & .013 & .026 & .140 & .079 & .013 & .259 & .476 & .578 & .000 \\
\hline
\end{tabular}

*. Correlation is significant at the 0.05 level (2-tailed). **. Correlation is significant at the 0.01 level (2-tailed). 
As per table 3, accounts receivable collection period did not have any strong correlation with any corporate governance variable. It had, however, a statistically significant but moderate association with the number of executive directors and the number of non-executive directors, although in opposite directions. Executive directors' number had a negative association while non-executive directors' number had a positive association.

Inventory conversion period had a statistically significant but moderate positive association with number of executive directors. Moreover, it reflected a statistically significant but moderate negative correlation with number of non-executive directors, female directors, sub-committee and board meetings.y.

The frequency of accounts payable payment reflected a moderate negative relationship with number of female directors and a positive association with board size, number of executive and non-executive directors and number of male directors. All these correlations were moderate and statistically significant.

Cash conversion cycle had a statistically significant and strong negative correlation with number of non-executive directors. The cycle also reflected a significant negative moderate correlation with board size, male directors and number of sub-committees. The debt ratio reflected a statistically significant positive strong association with number of sub-committees.

Statistically significant positive but moderate correlation was found between current ratio and numbers of executive directors. Current ratio also reflected statistically significant negative but moderate association with number of non-executive directors, number of sub-committees and number of board meetings. Further, a negative moderate association which is statistically significant was also found between quick ratio and number of sub-committees. Overall, in terms of strength and direction of the correlations, only two associations were found to be strong, that is, association between cash conversion cycle and number of non-executive directors, and the one between debt ratio and number of sub-committee. While it is not clear what can cause the significant strong positive relationship between debt ratio and number of sub-committee, it can be explained why the cash conversion cycle and number of non-executive directors may tend to move on opposite directions. As the number of executive directors increase, management in liquidity position may increase and thus reduce the cash conversion cycle.

Among the independent variables, board size had a statistically significant positive and strong association with number of non-executive directors $(r=0.866, \mathrm{P}=0.000)$ and male directors $(\mathrm{r}=0.968, \mathrm{P}=0.000)$. This finding indicates that board of directors in sampled companies were dominated by non-executive directors and male directors. A significant positive strong association was also found between non-executive directors and male directors $(r=0.763, \mathrm{P}=0.000)$.

To sum up the correlation analysis, Table 3 shows that $32 \%$ of 56 correlations computed between corporate governance elements and working capital components reflect either significant positive or significant negative but moderate associations at 0.01 level.

\subsection{Regression Analysis}

We first run the regression of all seven models with eight independent variables each. The results revealed that the models regressing working capital ratios on corporate governance variables appeared to be good predictors with their R-squared being above 50\% except for the average collection period model, which had R-squared of $42 \%$. All the relationships were statistically significant. However, due to high collinearity which existed among board size, non-executive directors and male directors as measured by correlation indicated above, number of non-executive directors and number of male directors were removed from the models to remain with six independent variables. The following models were therefore tested:

$$
\begin{aligned}
& A C P=\alpha+\beta_{1} B S E+\beta_{2} E X C+\beta_{5} F D S+\beta_{6} B G D+\beta_{7} N S C+\beta_{8} B M F+\varepsilon \\
& I C P=\alpha+\beta_{1} B S E+\beta_{2} E X C+\beta_{5} F D S+\beta_{6} B G D+\beta_{7} N S C+\beta_{8} B M F+\varepsilon \\
& A P P=\alpha+\beta_{1} B S E+\beta_{2} E X C+\beta_{5} F D S+\beta_{6} B G D+\beta_{7} N S C+\beta_{8} B M F+\varepsilon \\
& C C C=\alpha+\beta_{1} B S E+\beta_{2} E X C+\beta_{5} F D S+\beta_{6} B G D+\beta_{7} N S C+\beta_{8} B M F+\varepsilon \\
& D R=\alpha+\beta_{1} B S E+\beta_{2} E X C+\beta_{5} F D S+\beta_{6} B G D+\beta_{7} N S C+\beta_{8} B M F+\varepsilon \\
& C R=\alpha+\beta_{1} B S E+\beta_{2} E X C+\beta_{5} F D S+\beta_{6} B G D+\beta_{7} N S C+\beta_{8} B M F+\varepsilon \\
& Q R=\alpha+\beta_{1} B S E+\beta_{2} E X C+\beta_{5} F D S+\beta_{6} B G D+\beta_{7} N S C+\beta_{8} B M F+\varepsilon
\end{aligned}
$$

Table 4 presents the regression output of the seven models with six corporate governance variables after removing number of non-executive directors and number of male directors which were almost perfectly correlated with board size. Table 4 shows that in all seven models, moderate to high percentage of variations in 
the working capital elements can be attributed to changes in corporate governance factors namely board size, number of executive directors, number of female directors, percentage of female directors to total number of directors, number of subcommittees and number of board meeting per year. This finding supports the finding of Ahmad, Ahmed and Samim (2018) who concluded that, on the overall, governance parameters have significant impact on the working capital management efficiency. In this study all models have R-squared ranging from $43 \%$ to $82 \%$ and all of them are statistically significant. This implies that fluctuations in working capital management in this range can be explained by change in corporate governance variables. Average collection period (ACP) model recorded the lowest R-squared of $43 \%$ while inventory conversion period (ICP) registered the highest R-squared of $82 \%$.

Average collection period model revealed that $49 \%$ of variations can be explained by the change in the number of executive directors. This relationship is negative and significant at $5 \%$ level $(\mathrm{P}=0.023)$. Board size, number of female directors and number of subcommittees in an organisation have a non-significant positive relationship with accounts receivable collection efficiency while gender diversity and board meetings frequency have a non-significant negative relationship. The finding on the influence of board size to accounts receivable collection period is contrary to the findings of Chaudhry and Ahmad (2015) who found that board size had a significant negative influence on average collection period.

Board size, number of female directors and number of subcommittees have a significant negative relationship with inventory conversion period with p-values of $0.000,0.005$ and 0.006 respectively while number of executive directors in the board has a significant positive relationship $(\mathrm{p}=0.000)$. The significant negative impact of board size on inventory conversion cycle was also revealed by Chaudhry and Ahmad (2015) study. The results suggest that inventory conversion period would decrease by $44 \%$ if the board size increased and it would increase by $48 \%$ if the number of executive director increased.

Table 4. Regression analysis of ACP, ICP, APP, CCC, DR, CR and QR models

\begin{tabular}{|c|c|c|c|c|c|c|c|c|c|c|c|c|}
\hline \multirow[b]{2}{*}{ Model } & & \multicolumn{2}{|c|}{$\begin{array}{c}\text { Unstandardized } \\
\text { Coefficients } \\
\end{array}$} & \multicolumn{3}{|c|}{$\begin{array}{l}\text { Standardized } \\
\text { Coefficients }\end{array}$} & \multicolumn{2}{|c|}{$\begin{array}{l}\text { Collinearity } \\
\text { Statistics }\end{array}$} & \multicolumn{2}{|c|}{ Model Summary } & \multicolumn{2}{|c|}{ ANOVA } \\
\hline & & $\mathrm{B}$ & Std. Error & Beta & $\mathrm{t}$ & Sig. & Tolerance & VIF & R-Square & Adjusted R-Square & $\mathrm{F}$ & Sig \\
\hline \multirow[t]{8}{*}{$\overline{\mathrm{ACP}}$} & & & & & & & & & .432 & .315 & 3.682 & $.008^{\mathrm{b}}$ \\
\hline & (Constant) & 11.964 & 8.829 & & 1.355 & .186 & & & & & & \\
\hline & BSE & 0.841 & 0.606 & .237 & 1.389 & .176 & .674 & 1.484 & & & & \\
\hline & EXC & -3.403 & 1.422 & -.492 & -2.394 & .023 & .464 & 2.157 & & & & \\
\hline & FDS & 2.445 & 2.859 & .179 & 0.855 & .399 & .447 & 2.235 & & & & \\
\hline & BGD & -9.305 & 6.970 & -.218 & -1.335 & .192 & .732 & 1.367 & & & & \\
\hline & NSC & 1.598 & 0.941 & .333 & 1.698 & .100 & .508 & 1.968 & & & & \\
\hline & $\mathrm{BMF}$ & -1.246 & 1.607 & -.144 & -0.775 & .445 & .563 & 1.776 & & & & \\
\hline \multirow[t]{8}{*}{ ICP } & & & & & & & & & .816 & .778 & 21.448 & $.000^{\mathrm{b}}$ \\
\hline & (Constant) & 120.748 & 28.028 & & 4.308 & .000 & & & & & & \\
\hline & BSE & -8.682 & 1.923 & -.438 & -4.514 & .000 & .674 & 1.484 & & & & \\
\hline & EXC & 18.669 & 4.513 & .484 & 4.137 & .000 & .464 & 2.157 & & & & \\
\hline & FDS & -27.593 & 9.077 & -.362 & -3.040 & .005 & .447 & 2.235 & & & & \\
\hline & BGD & -19.573 & 22.129 & -.082 & -.885 & .384 & .732 & 1.367 & & & & \\
\hline & NSC & -8.944 & 2.988 & -.334 & -2.993 & .006 & .508 & 1.968 & & & & \\
\hline & BMF & .871 & 5.103 & .018 & .171 & .866 & .563 & 1.776 & & & & \\
\hline \multirow[t]{8}{*}{ APP } & & & & & & & & & .529 & .432 & 5.432 & $.001^{\mathrm{b}}$ \\
\hline & (Constant) & -7.232 & 32.749 & & -.221 & .827 & & & & & & \\
\hline & BSE & 8.874 & 2.247 & .613 & 3.949 & .000 & .674 & 1.484 & & & & \\
\hline & EXC & 3.860 & 5.273 & .137 & .732 & .470 & .464 & 2.157 & & & & \\
\hline & FDS & -6.651 & 10.606 & -.119 & -.627 & .536 & .447 & 2.235 & & & & \\
\hline & BGD & 6.773 & 25.856 & .039 & .262 & .795 & .732 & 1.367 & & & & \\
\hline & NSC & .636 & 3.492 & .033 & .182 & .857 & .508 & 1.968 & & & & \\
\hline & BMF & -8.777 & 5.963 & -.250 & -1.472 & .152 & .563 & 1.776 & & & & \\
\hline \multirow[t]{3}{*}{$\mathrm{CCC}$} & & & & & & & & & .625 & .547 & 8.044 & $.000^{\mathrm{b}}$ \\
\hline & (Constant) & 139.688 & 46.061 & & 3.033 & .005 & & & & & & \\
\hline & BSE & -16.726 & 3.161 & -.733 & -5.291 & .000 & .674 & 1.484 & & & & \\
\hline
\end{tabular}




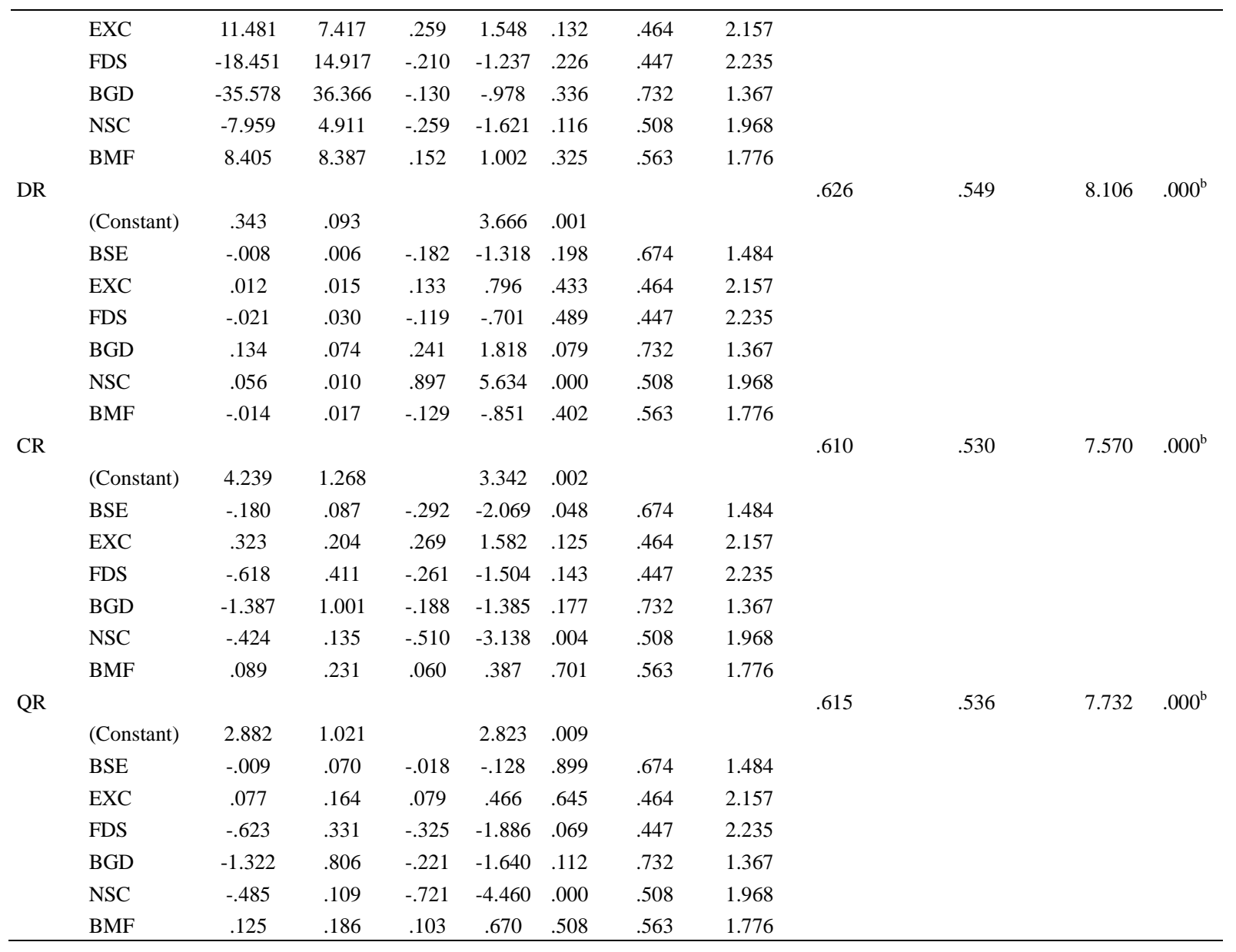

Average payment period model (APP), yielded R-square of 0.529 implying that almost $53 \%$ change in accounts payable period can be explained by the changes in a combination of corporate governance elements examined. The model also indicates that the only predicting factor of accounts payable payment period is the size of the board of directors. Apparently, the increase in board size would result in $61 \%$ increase in the period companies stay with their creditors' money, and the results were statistically significant $(\mathrm{p}=0.000)$. However, these results are contrary to findings of Jamalinesari and Soheili (2015) who found a negative and significant relationship between board size and accounts payable period.

The Cash conversion cycle model (CCC), indicated that a combination of corporate governance elements can explain $62.5 \%$ of the fluctuations in the cash conversion cycle. However, board size seemed to have the strongest negative effect on the cash conversion cycle (Beta $=-0.733, \mathrm{P}=0.000$ ) implying that an increase in the number of board directors would result in a decrease in the cash conversion cycle by $73 \%$. Normally the shorter the cash conversion cycle the better for the business, therefore, according to this result the increase in board size has the potential of increasing liquidity in an organization. These results are in agreement with the findings of Chaudhry and Ahmad (2015) and Jamalinesari and Soheili (2015) but in contrast with findings by Sadegh Zadeh (2016) who found a significant positive relationship between board size and management efficiency of cash conversion cycle.

The Debt ratio had a moderate R-squared of about $63 \%$ which was statistically significant. The number of subcommittees recorded about $90 \%$ statistically significant positive effect on Debt ratio . Number of executive directors and board gender diversity reflected a weak positive relationship with Debt ratio while the board size, number of female directors and meetings frequency registered a non-significant negative weak relationship with Debt ratio.

Current ratio and Quick Ratio recorded R-square of about $61 \%$ each which were statistically significant. This shows that $61 \%$ of variations in current ratio and quick ratio can be attributed to the combination of corporate governance mechanisms. Number of sub-committees reflected the significant negative relationship with current ratio of 51\%. This implies that the increase in the number of subcommittees will result in $51 \%$ decline in current 
ratio. Board size, number of female director and board gender diversity had a non-significant negative low impact on current ratio. These findings do not support the findings of Ahmad, Ahmed, and Samim (2018) who found a significant positive relationship between both board size and audit committee with current ratio. Number of executive director had a non-significant positive low relationship with current ratio. The number of subcommittees had a significant strong negative relationship with quick ratio. The results show that an increase in number of subcommittees would result in decline in quick ratio by $72 \%$. Moreover, an insignificant negative relationship was observed between quick ratio and board size, number of female directors and board gender diversity. The impact of number of executive directors and board meeting frequency on quick ratio was found to be positive but weak and insignificant.

Overall, the findings of this study suggest that internal corporate governance mechanisms have an impact on working capital elements as supported by prior studies, for example; Ahmad, Ahmed and Samim (2018), Ali and Shah (2017) and Kamau and Basweti (2013). Specifically, looking at corporate governance elements in each model with highest Betas, it is observed that number of executive directors had a significant negative impact on days of collecting cash from accounts receivable and a significant positive impact on inventory conversion cycle. This shows the importance of executive directors' decisions on working capital management. It is again observed, that the board size had a significant positive effect on accounts payable payment period and a significant negative impact on cash conversion. Number of subcommittees had a significant positive impact on the extent of financial leverage of the firms and had a significant negative effect on current ratio and quick ratio. In summary, corporate governance mechanisms in Consumer Services listed companies have noticeable significant impact on working capital management efficiency.

\subsection{Summary of Findings}

The key findings from correlation analysis were as follows:

1) BSE has a significant positive but moderate association with APP and a significant negative moderate association with CCC.

2) EXC has a significant positive but moderate association with ICP, $C R$ and $Q R$.

3) NEX has a significant negative but moderate association with ICP, CCC and CR.

4) MDS has a significant positive but moderate association with APP and a significant negative moderate association with CCC.

5) FDS has significant negative but moderate association with ICP and APP.

6) NSC has a significant negative but moderate association with ICP, CCC, CR and QR and a significant positive moderate association with DR.

7) BMF has a significant negative but moderate association with ICP.

The regression analysis revealed the following major findings:

1) Corporate governance mechanisms have significant positive and strong impact on ICP.

2) Corporate governance mechanisms have a significant positive but moderate impact on $\mathrm{DR}, \mathrm{CCC}, \mathrm{QR}, \mathrm{CR}$, and APP.

3) Corporate governance mechanisms have significant positive but weak impact on ACP.

The findings of this study to a very large extent agree with the findings of Gill and Biger (2013), Kamau and Basweti (2013), Karani (2013), Chaudhry and Ahmad (2015), Kamel (2016), Faradonbeh and Dolatabadi, (2015), Jamalinesari and Soheili (2015), Meshack (2015), Al-Rahahleh (2016), Ali and Shah (2017) and Ahmad, Ahmed and Samim (2018).

\section{Conclusion and Recommendations}

This study investigated the impact of corporate governance mechanisms on the working capital management efficiency. Several working capital components were regressed on a number of corporate governance elements. The results of this study suggest a vivid relationship between corporate governance and working capital management. A significant and strong positive effect of corporate governance mechanisms on both inventory conversion and cash conversion cycle is a clear indication of how crucial corporate governance is on survival of an organization. It is, therefore, recommended that the board of directors should closely work with managers to ensure that good working capital decisions are taken to improve shareholders' value.

This study focused on six listed companies in the consumer services sector for the period 2012-2017. A study in 
the future with extended data set on both corporate governance and working capital components might provide more detailed information on the impact of corporate governance on working capital management efficiency. Despite the aforesaid limitations, the study provides an understanding of the impact of corporate governance on the working capital management efficiency of listed retail companies in Botswana. Further studies in this area may employ mixed-methods approach to get the insights of the executives regarding the impact of corporate governance on working capital management efficiency. This could be achieved through the analysis of secondary data of listed companies followed by in-depth interviews with executives to elicit their views on the relationships between corporate governance and working capital management.

\section{References}

Ahmad, B., Ahmed, I., \& Samim, M. M. (2018). Working Capital Management Efficiency and Corporate Governance in Manufacturing Sector of Pakistan. European Online Journal of Natural and Social Sciences, 7(1), 67-87.

Ali, B., \& Shah, S. (2017). The Impact of Corporate Governance on Working Capital Management Efficiency: A Quantitative Study Based On Pakistani Manufacturing Firms. City University Research Journal, 7(2), 272-284

Alnaser, N., Shaban, O. S., \& Al-Zubi, Z. (2014). The effect of effective corporate governance structure in improving investors' confidence in the public financial information. International Journal of Academic Research in Business and Social Sciences, 4(1), 556-569.

Al-Rahahleh, A. S. (2016). Corporate Governance Quality and Cash Conversion Cycle: Evidence from Jordan. International Business Research, 9(10), 140. https://doi.org/10.5539/ibr.v9n10p140

Bergen, M., Dutta, S., \& Walker Jr, O. C. (1992). Agency relationships in marketing: A review of the implications and applications of agency and related theories. The Journal of Marketing, 1-24. https://doi.org/10.2307/1252293

Berle, A., \& Means, G. (1932). The Modern Corporation and Private Property. New York, NY: Macmillan.

Chaudhry, A., \& Ahmad, N. (2015). Does Corporate Governance Affect Working Capital Management Efficiency Of Firms? Evidence from Manufacturing Sector of Pakistan. Science International (Lahore), 27(6), 6255-6260.

Claessens, S. (2003) Corporate Governance and Development Global Corporate Governance Forum Focus 1. Washington: World Bank.

Davis, J., Frankforter, S., Vollrath, D., \& Hill, V. (2007). An empirical test of stewardship theory. Journal of Business \& Leadership: Research, Practice, and Teaching (2005-2012), 3(1), 40-50.

Deloof, M. (2003). Does working capital management affect profitability of Belgian firms? Journal of Business Finance \& Accounting, 30(3-4), 573-588. https://doi.org/10.1111/1468-5957.00008

Dittmar, A., \& Mahrt-Smith, J. (2007). Corporate governance and the value of cash holdings. Journal of financial economics, 83(3), 599-634. https://doi.org/10.1016/j.jfineco.2005.12.006

Drobetz, W., Grüninger, M. C., \& Hirschvogl, S. (2010). Information asymmetry and the value of cash. Journal of Banking \& Finance, 34(9), 2168-2184. https://doi.org/10.1016/j.jbankfin.2010.02.002

Elhabib, M. A., Rasid, E. S., \& Basiruddin, R. (2015). Why does Corporate Governance Become So Important? An Attempt to Identify the Major Causes for Calls to Improve Corporate Governance. European Journal of Business and Management, 7(31), 122-125.

Fama, E. F., \& Jensen, M. C. (1983). Separation of ownership and control. The Journal of Law and Economics, 26(2), 301-325. https://doi.org/10.1086/467037

Faradonbeh, H. A., \& Dolatabadi, H. R. (2015). Impact of corporate governance on the current assets management of the companies listed in Tehran stock exchange. Indian Journal of Fundamental and Applied Life Sciences, 5(S1), 1742-1751.

Fayezi, S., O'Loughlin, A., \& Zutshi, A. (2012). Agency theory and supply chain management: A structured literature review. Supply Chain Management: An International Journal, 17(5), 556-570. https://doi.org/10.1108/13598541211258618

Gill, A. S., \& Biger, N. (2013). The impact of corporate governance on working capital management efficiency of American manufacturing firms. Managerial Finance, 39(2), 116-132. 
https://doi.org/10.1108/03074351311293981

Gill, A., \& Shah, C. (2012). Determinants of corporate cash holdings: Evidence from Canada. International Journal of Economics and Finance, 4(1), 70-79.

Gill, A., Biger, N., \& Obradovich, J. (2014). The impact of independent directors on the cash conversion cycle of american manufacturing firms. International Journal of Economics and Finance, 7(1), 87-96. https://doi.org/10.5539/ijef.v7n1p87

Goel, U., Bansal, N., \& Sharma, A. (2015). Impact of Corporate Governance Practices on working Capital Management Efficiency: A Structural Equation Modelling Approach. Indian Journal of Finance, 9(1), 38-48. https://doi.org/10.17010/ijf/2015/v9i1/71534

Homayoun, S., \& Homayoun, S. (2015). Agency theory and corporate governance. International Business Management, 9(5), 805-815.

Jamalinesari, S., \& Soheili, H. (2015). The relationship between the efficiency of working capital management companies and corporate rule in Tehran Stock Exchange. Procedia-Social and Behavioral Sciences, 205, 499-504. https://doi.org/10.1016/j.sbspro.2015.09.052

Jensen, M. C., \& Meckling, W. H. (1976). Theory of the firm: Managerial behavior, agency costs and ownership structure. Journal of Financial Economics, 3(4), 305-360. https://doi.org/10.1016/0304-405X(76)90026-X

Kamau, S., \& Basweti, K. (2013). The Relationship between Corporate Governance and Working Capital Management Efficiency of Firms Listed At the Nairobi Securities Exchange. Research Journal of Finance and Accounting, 4(19), 190-199.

Kamel, S. R. (2016). The impact of corporate governance and firm maturity on working capital management efficiency: Evidence from listed European firms (Master of Science in Finance Thesis, The American University in Cairo).

Karani, H. (2013). The Effect of Corporate Governance on Working Capital of Manufacturing Firms Listed at the Nairobi Securities Exchange. Unpublished Master of Business Administration Thesis: University of Nairobi.

Kargar, J., \& Blumenthal, R. A. (1994). Leverage impact on working capital in small businesses. TMA Journal, $14,46-46$.

Kuan, T. H., Li, C. S., \& Chu, S. H. (2011). Cash holdings and corporate governance in family-controlled firms. Journal of Business Research, 64(7), 757-764. https://doi.org/10.1016/j.jbusres.2010.07.004

Lau, J., \& Block, J. H. (2012). Corporate Cash Holdings and their Implications on Firm Value in Family and Founder Firms. Corporate Ownership and Control, 9(4), 309-326. http://dx.doi.org/10.2139/ssrn.2000175

Lazaridis, I., \& Tryfonidis, D. (2006). Relationship between working capital management and profitability of listed companies in the Athens stock exchange.

Meshack, S. N. (2015). Influence of corporate governance practices on working capital efficiency of manufacturing firms in Nairobi County (Master of Business Administration Thesis, South Eastern Kenya University).

Mukhopadhyay, D. (2004). Working capital management in heavy engineering firms-A case study. Mangement Accountant Caluctta, 39, 317-323.

Njoku, G. C. (2017). The Impact of Corporate Governance on Working Capital Management in Nigerian Organizations. Doctoral Thesis: Walden Dissertations and Doctoral Studies Collection at Scholar Works, Walden University

Panda, B., \& Leepsa, N. M. (2017). Agency theory: Review of Theory and Evidence on Problems and Perspectives. Indian Journal of Corporate Governance, 10(1), 74-95. https://doi.org/10.1177/0974686217701467

Ronen, J., Kashi, R., \& Balachandran. (1995). Agency theory: An approach to incentive problems in management accounting. Asian Review of Accounting, 3(1), 127-151. https://doi.org/10.1108/eb060655

Sadegh, Z. A. (2016). The Impact of Corporate Governance on Cash Management Efficiency in the Industry of Machinery and Equipment. International Journal of Scientific Management and Development, 4(4), 126-130.

Sundaramurthy, C., \& Lewis, M. (2003). Control and collaboration: Paradoxes of governance. Academy of 
Management Review, 28(3), 397-415. https://doi.org/10.2307/30040729

Wasiuzzaman, S., \& Arumugam, V. C. (2013). Determinants of Working Capital Investment: A Study of Malaysian Public Listed Firms. Australasian Accounting, Business and Finance Journal, 7(2), 63-83. https://doi.org/10.14453/aabfj.v7i2.5

Yusoff, W. F. W., \& Alhaji, I. A. (2012). Insight of corporate governance theories. Journal of Business and Management, 1(1), 52-63. https://doi.org/10.12735/jbm.v1i1p52

\section{Copyrights}

Copyright for this article is retained by the author(s), with first publication rights granted to the journal.

This is an open-access article distributed under the terms and conditions of the Creative Commons Attribution license (http://creativecommons.org/licenses/by/4.0/). 